\title{
US carcinogen control threatened by costs
}

THE US Department of Labour's Occupational Safety and Health Administration (OSHA) seems to be losing the fierce battle that it has put up against being required to carry out detailed cost-benefit analyses of attempts to regulate occupational exposure to toxic substances.

OSHA director Dr Eula Bingham, previously professor of environmental bealth at the University of Cincinnati Medical School, remains adamant that such analysis is not required by the Occupational Safety and Health Act of 1969 , beyond ensuring that no action threatens the overall survival of a particular industry.

OSHA is far from giving in to the attacks of those who claim that further regulation is merely aggravating the country's inflation problems. This week, for example, the Department of Labour was expected to announce a new standard for occupational exposure to lead of 50 micrograms per cubic metre of air-four times lower than existing permitted levels-despite its own studies showing that this will have a substantial economic impact on the lead-storage battery industry.

However, two recent events indicate the increasing pressure on OSHA to act not just on scientific evidence-or lack of evidence as the case may beto protect workers' health but also to consider the economic implications.

The first is a statement from the Regulatory Analysis and Review Group, an offspring of the Council on Wage and Price Stability widely distrusted by environmental and labour groups. In its comment on OSHA's proposed scheme for classifying and regulating chemical carcinogens, the review group echoed opposition to the scheme by the US chemical industry, criticised its 'inflexilibity' and claimed that the cost of implementing it would be "potentially quite substantial, well in excess of $\$ 1$ billion."

Similar pressures are also beginning to come through the courts. Last month, a federal appeals court in New Orleans set aside proposed new benzene exposure rules proposed by OSHA in June, on the grounds that the agency had failed to demonstrate a "reasonable relationship" between anticipated benefits and costs.

OSHA has already indicated that it will appeal against the court's ruling, a significant departure from earlier legal decisions which had accepted that such cost-benefit analysis was not necessary. But it accepts that if the ruling stands, then it would be required to shift its strategy; "if one has enough interpretations that this is demanded, then one would do it", Dr Bingham said. The agency's reluctance to engage in such analysis seems based on three fears about how it might undermine OSHA's mandated efforts to protect the health of US workers. The first is that a requirement to carry out detailed cost-benefit studies would overburden an understaffed agency.

The second fear is that, as far as information on costs is concerned, OSHA would have to rely heavily on data provided by the industry itself, which it feels might be overstated.

Thirdly there is a feeling that occupational health is an area in which scientific uncertainties are so high that any attempt to place definitive values on degrees of risk, etc., would merely disguise how such judgments reflect broader social values, and that these

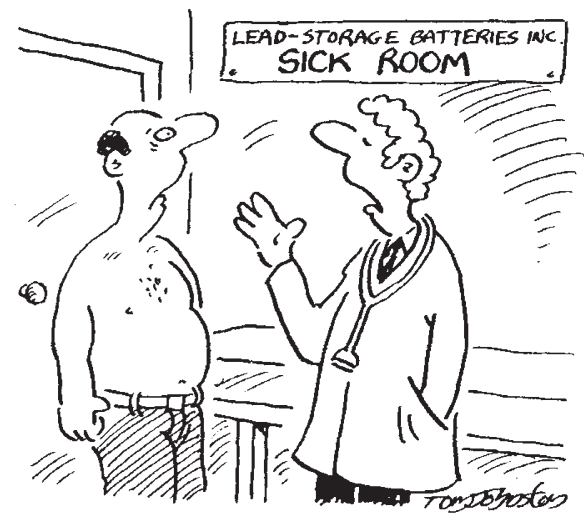

"You're suffering from a bad case of Federal Appeals Court decisions, aggravated by inflation problems!"

could be better dealt with if openly acknowledged.

"There is in scientific terms no evidence of a 'threshold'. But there is evidence that as you reduce the exposures, you are reducing the risk. If there are a few fibres or molecules left, theoretically someone somewhere might get cancer from it. At that point a social decision has to be made," according to Dr Irving J. Selikoff director of environmental sciences, Mount Sinai Hospital, New York.

The problems caused by the scientific uncertainties were illustrated by the public controversy last month over a statement released by the National Cancer Institute, the National Institute of Environmental Health Sciences, and the National Institute for Occupational Safety and Health, claiming that up to $20 \%$ of all cancer deaths might be attributable to occupational exposure.

Erroneously described by the US media as the results of a "new federal study", and frequently hardened to the claim that $20 \%$ of cancers were attributable to such exposure, the report was in fact a position paper put together rather hurriedly to meet OSHA's deadline for comments on its carcinogen proposals-and was given premature publicity when Labour Secretary Ray Marshall quoted extracts at a trade union conference.

The main message of the statement is that earlier estimates suggesting one to five per cent of cancers can be attributed to occupational exposure appear to be "unrealistically low".

However, the American Industrial Health Council, an industry-sponsored group which has been leading the attack on OSHA's carcinogen proposals, criticised the $20 \%$ figure as based on "unwarranted speculation".

Emphasising the council's support for the one to five per cent estimate, Dr Fred Hoerger, chairman of the AIHC's scientific committee, said that "the predicted massive increase in cancer due to occupational exposure in the study is not supported by current knowledge of cancer rates, worker exposures, or numbers of workers exposed".

The debate has demonstrated the gulf that exists between the scientifically conceivable (represented by the NCI position), and the scientifically demonstrable (on which AIHC argues regulation should be based).

It is a gulf which OSHA feels would be prematurely foreclosed by translating the debate into one of costs against benefits, given the problems of adequately defining either. Industry has been impressing on the president's economic advisers that, with rapidly rising production costs, this is the only reasonable basis for legislation.

OSHA has so far taken a firm stand against being required to adopt industry's perspective. And it has suffered virulent attacks, such as the American Conservative Union's "Stop OSHA" campaign, for doing so. But it is not yet prepared to throw in the towel.

David Dickson

\section{Correction}

On page 108 of last week's issue a small error may have caused some confusion in interpreting the UK's proposed new guidelines for genetic manipulation. In the third column, item 4 , the experiments referred to are those listed under the third item in the box on pages 106 and 107, that is those in Category I* "for which at present there is no substantial evidence of risk. The chief candidates of this kind are the experiments in which $E$. coli genes are cloned in E. coli organisms". 